\title{
Addressing a silent and neglected scourge in sexual and reproductive health in Sub-Saharan Africa by development of training competencies to improve
} prevention, diagnosis, and treatment of female genital schistosomiasis (FGS) for health workers

\author{
Julie Jacobson ${ }^{1 *} \mathbb{D}$, Anastasia Pantelias ${ }^{1}$, Megan Williamson ${ }^{1,2}$, Eyrun Floerecke Kjetland ${ }^{3,7}$, Alison Krentel ${ }^{4}$, \\ Margaret Gyapong ${ }^{5}$, Pamela Sabina Mbabazi ${ }^{6}$ and Amadou Garba Djirmay ${ }^{6}$
}

\begin{abstract}
Background: Schistosomiasis is an acute and chronic disease caused by parasitic worms, that can take two main forms: intestinal or urogenital. If left untreated, the urogenital form can lead to female genital schistosomiasis (FGS) in women and girls; frequently resulting in severe reproductive health complications which are often misdiagnosed as sexually-transmitted infections (STIs) or can be confused with cervical cancer. Despite its impact on women's reproductive health, FGS is typically overlooked in medical training and remains poorly recognized with low awareness both in affected communities and in health professionals. FGS has been described as the one of the most neglected sexual and reproductive health issues in sub-Saharan Africa (Swai in BMC Infect Dis 6:134, 2006; Kukula in PLoS Negl Trop Dis 13:e0007207; Joint United Nations Programme on HIV/AIDS (UNAIDS) 2019). Increased knowledge and awareness of FGS is required to end this neglect, improve women's reproductive health, and decrease the burden of this preventable and treatable neglected tropical disease.

Methods: We conducted interactive virtual workshops, in collaboration with the World Health Organization (WHO), engaging 64 participants with medical and public health backgrounds from around the world to establish standardized skills (or competencies) for prevention, diagnosis, and treatment of FGS at all levels of the health system. The competencies were drafted in small groups, peer-reviewed, and finalized by participants.

Results: This participatory process led to identification of 27 skills needed for FGS prevention, diagnosis, and management for two categories of health workers; those working in a clinical setting, and those working in a community setting. Among them, ten relate to the diagnosis of FGS including three that involve a pelvic exam and seven that do not. Six constitute the appropriate behaviors required to treat FGS in a clinical setting. Eleven address the community setting, with six relating to the identification of women at risk and five relating to prevention.
\end{abstract}

Conclusion: Defining the skills necessary for FGS management is a critical step to prepare for proper diagnosis and treatment of women and girls in sub-Saharan Africa by trained health professionals. The suggested competencies can

\footnotetext{
*Correspondence: jjacobson@bridgestodevelopment.org

1 Bridges to Development, Washington, USA

Full list of author information is available at the end of the article
} permits use, sharing, adaptation, distribution and reproduction in any medium or format, as long as you give appropriate credit to the original author(s) and the source, provide a link to the Creative Commons licence, and indicate if changes were made. The images or other third party material in this article are included in the article's Creative Commons licence, unless indicated otherwise in a credit line to the material. If material is not included in the article's Creative Commons licence and your intended use is not permitted by statutory regulation or exceeds the permitted use, you will need to obtain permission directly from the copyright holder. To view a copy of this licence, visit http://creativecommons.org/licenses/by/4.0/. The Creative Commons Public Domain Dedication waiver (http://creativeco mmons.org/publicdomain/zero/1.0/) applies to the data made available in this article, unless otherwise stated in a credit line to the data. 
now serve as the foundation to create educative tools and curricula to better train health care workers on the prevention, diagnosis, and management of FGS.

Keywords: Female genital schistosomiasis (FGS), Schistosomiasis, Neglected tropical diseases (NTD), Reproductive health, Health equity, HIV, Cervical cancer, Colposcopy, Sub-Saharan Africa

\title{
Combattre un fléau silencieux et négligé dans le domaine de la santé sexuelle et reproductive en Afrique subsaharienne par le développement de compétences, pour améliorer la prévention, le diagnostic et le traitement de la bilharziose génitale féminine (BGF) par les travailleurs de la santé
}

\begin{abstract}
Résumé
Introduction: La bilharziose ou schistosomiase est une maladie aiguë et chronique causée par des parasites, qui peut prendre deux formes principales: intestinale ou urogénitale. Si elle n'est pas traitée, la forme urogénitale peut conduire à une bilharziose génitale féminine (BGF) entraînant fréquemment de graves complications en matière de santé reproductive chez les femmes et les jeunes filles. Les séquelles physiques causées par la BGF sont souvent mal diagnostiquées et fréquemment confondues avec celles causées par des infections sexuellement transmissibles (IST) ou des cancers du col de l'utérus. Malgré son impact sur la santé reproductive des femmes, la BGF est généralement négligée dans la formation médicale et reste méconnue, avec une faible sensibilisation à la fois dans les communautés touchées et chez les professionnels de la santé. La BGF a été décrite comme l'un des problèmes de santé sexuelle et reproductive les plus négligés en Afrique subsaharienne (Swai in BMC Infect Dis 6:134, 2006; Kukula in PLoS Negl Trop Dis 13:e0007207; Joint United Nations Programme on HIV/AIDS (UNAIDS) 2019). Une meilleure connaissance et une plus grande sensibilisation à la BGF sont nécessaires pour mettre fin à cette négligence, améliorer la santé reproductive des femmes et diminuer le fardeau de cette maladie tropicale négligée évitable et traitable.

Méthode: Nous avons organisé des ateliers virtuels interactifs en collaboration avec l'Organisation mondiale de la santé (OMS), réunissant 64 participants du monde entier formés en médecine ou santé publique, afin d'établir des aptitudes (ou compétences) requises pour la prévention, le diagnostic et le traitement des BGF à tous les niveaux du système de santé. Les compétences ont été rédigées en petits groupes, révisées par des pairs et finalisées par les participants eux-mêmes.
\end{abstract}

Résultats: Ce processus participatif a permis d'identifier 27 compétences nécessaires à la prévention, au diagnostic et au traitement de la BGF pour deux catégories de professionnels de santé: ceux travaillant dans un cadre clinique et ceux travaillant dans un cadre communautaire. Parmi celles qui concernent le milieu clinique, dix compétences sont liées au diagnostic de la BGF, dont trois impliquant un examen pelvien et sept n'en impliquant pas. Six se réfèrent aux comportements requis pour traiter adéquatement la BGF. Parmi les onze compétences qui concernent le milieu communautaire, six ont trait à l'identification des femmes à risque et cinq à la prévention.

Conclusion: Définir les compétences nécessaires à la prise en charge de la BGF est une étape essentielle qui permettra de progresser vers un diagnostic et un traitement adéquat des femmes et des filles en Afrique subsaharienne par des professionnels de santé qualifiés. Les compétences suggérées peuvent dès à présent servir de base à la création d'outils éducatifs et de programmes d'enseignement pour mieux former les travailleurs de la santé à la prévention, au diagnostic et au traitement de la BGF. 


\title{
Enfrentando um flagelo silencioso e
} negligenciado na saúde sexual e reprodutiva na África Subsaariana através do desenvolvimento de competências de treinamento para melhorar a prevenção, diagnóstico e tratamento da esquistossomose genital feminina (EGF) para trabalhadores de saúde

\begin{abstract}
Resumo
Contexto: A esquistossomose é uma doença aguda e crônica causada por vermes parasitas, que se apresenta de duas formas principais: intestinal ou urogenital. Se não for tratada, a forma urogenital pode resultar em mulheres e meninas à esquistossomose genital feminina (EGF); frequentemente resultando em graves complicações na saúde reprodutiva que são por vezes mal diagnosticadas como doenças sexualmente transmissíveis (DSTs) ou podem ser confundidas com câncer cervical. Apesar de seu impacto na saúde reprodutiva da mulher, a EGF é normalmente negligenciada no treinamento de saúde e permanece pouco reconhecida, com baixa conscientização tanto nas comunidades afetadas, como para os profissionais de saúde. A EGF tem sido descrita como uma das questões de saúde sexual e reprodutiva mais negligenciadas na África Subsaariana (Swai in BMC Infect Dis 6:134, 2006; Kukula in PLoS Negl Trop Dis 13:e0007207; Joint United Nations Programme on HIV/AIDS (UNAIDS) 2019). Um maior conhecimento e conscientização da EGF é necessário para acabar com esta negligência, melhorar a saúde reprodutiva das mulheres e diminuir o peso desta doença tropical negligenciada que é previnível e tratável.
\end{abstract}

Metodologia: Realizamos workshops virtuais interativos, em colaboração com a Organização Mundial da Saúde (OMS), envolvendo 64 participantes com formação médica e de saúde pública de todo o mundo para estabelecer as habilidades (ou competências) padronizadas para prevenção, diagnóstico e tratamento de EGF em todos os níveis do sistema de saúde. As competências foram redigidas em pequenos grupos, revisadas por pares e concluídas pelos participantes.

Resultados: Este processo participativo levou à identificação de 27 habilidades necessárias para a prevenção, diagnóstico e gestão da EGF para duas categorias de trabalhadores da saúde; aqueles que trabalham em um ambiente clínico, e aqueles que trabalham em um ambiente comunitário. Entre elas, dez estão relacionadas ao diagnóstico da EGF, incluindo três que envolvem um exame pélvico e sete que não o realizam. Seis constituem as condutas adequadas necessárias para tratar a EGF em um ambiente clínico. Onze tratam do ambiente comunitário, sendo seis relacionados à identificação de mulheres em risco e cinco relacionados à prevenção.

Conclusão: Definir as habilidades necessárias para a administração da EGF é um passo crítico para proporcionar o diagnóstico e tratamento adequado de mulheres e meninas na África Subsaariana por profissionais de saúde treinados. As competências sugeridas podem agora servir como base para criar ferramentas educativas e currículos para melhor treinar os profissionais de saúde na prevenção, diagnóstico e gestão da EGF.

\section{Plain Language Summary}

Schistosomiasis belongs to the group of neglected tropical diseases (NTDs) found in tropical and subtropical countries, disproportionately affecting poor populations with limited access to safe water and adequate sanitation. Female genital schistosomiasis (FGS) is a chronic disease caused by parasitic worms, schistososomes, transmitted by contact with infested fresh water. When left untreated, FGS can lead to severe reproductive health complications, such as sub-or infertility and ectopic pregnancy. FGS is a leading neglected issue in sexual and reproductive health in sub-Saharan 


\begin{abstract}
Africa; however, health professionals are not familiar with it, leading to misdiagnosis and improper treatment. A critical challenge in addressing the burden of FGS is the knowledge gap about the disease in communities and health professionals in endemic areas and the world at large. As part of an FGS Accelerated Scale Together (FAST) package, and in an attempt to address the knowledge gap in health professionals, we organized an interactive workshop bringing together a group of 64 participants working in sexual and reproductive health generally, and/or FGS specifically. Together, we developed a comprehensive set of required skills for health workers training on FGS. The workshop participants drafted 27 skills (or competencies) to diagnose, treat, and prevent FGS. Establishing what health workers must know is a crucial first step towards the integration of FGS into women's health care. The competencies are now available and can be used as a framework in the development of training for health professionals, opening the doors to better reproductive health for women.
\end{abstract}

\section{Background}

Schistosomiasis is an acute and chronic disease caused by parasitic worms, that can take two main forms: intestinal or urogenital [4]. According to the World Health Organization (WHO), in 2019 there were almost 240 million schistosomiasis infections worldwide, causing an estimated 3.3 million disability-adjusted life-years [2]. The number of deaths due to schistosomiasis is estimated between 24,067 and 200,000 globally each year, the highest mortality among the neglected tropical diseases recognized by the WHO [5]. Sub-Saharan African bears the majority of the global burden, reporting at least $93 \%$ of cases [6].

Schistosomiasis is transmitted through contact with contaminated fresh water sources during normal daily activities, like washing, bathing, cooking, or swimming (Fig. 1) [6, 7]. Although there are several species of parasitic worms that can cause schistosomiasis, approximately two-thirds of cases are due to infection with $S$. haematobium, the primary cause of urogenital disease including female genital schistosomiasis (FGS). FGS is estimated to affect up to 56 million women and girls in Africa [8]. For example, a pilot study conducted in four rural communities in Ogun State in Nigeria showed schistosomiasis infection rates for women of up to $47 \%$ [9]. In Ghana, urinary schistosomiasis prevalence among women in the Volta basin was $24.8 \%$ while $10.6 \%$ of them were diagnosed with female genital schistosomiasis (FGS) [10].

Urogenital schistosomiasis affects both the urinary and genital track of infected individuals when eggs released by adult worms implant in tissue in the urogenital system of the infected host. The urinary signs and symptoms are easily recognized, with bloody urine often being the first sign of infection and typically what is described in medical training. Female genital symptoms include vaginal discharge, post-coital bleeding, genital burning, and/or pelvic pain [5]. If left untreated, infection can lead to more severe complications related to women's reproductive health, characterized by anemia, sub- or infertility, spontaneous abortion, and ectopic pregnancy [11]. Community-based studies in two S. haematobium-endemic areas in Zimbabwe, reported that $15 \%$ of women suffered from infertility with an odds ratio (OR) of 3.6 for FGS [12]. A study analyzing DHS data in Ethiopia, Uganda, Kenya, and Tanzania demonstrated that women in S. haematobium-endemic areas had a significantly higher OR for infertility than those living in nonendemic areas suggesting that FGS may be an underlying factor [12]. A study conducted in Ghana, comparing 41 pregnant women infected with S. haematobium to 500 noninfected women, showed that the risk of premature birth was higher $(34.8 \%)$ in infected women, compared to the others (23.8\%) [13]. However, reliable and detailed data on the consequences of schistosomiasis and birth outcomes is still limited.

In addition to the pathology from the infection directly, FGS is a plausible risk factor for HIV acquisition [14-17] and cervical cancer $[11,18,19]$ due to the tissue pathology, mucosal changes, and local immunologic modulations associated with FGS [20, 21]. In fact, studies across sub-Saharan Africa have shown a strong association between HIV prevalence and FGS [5]. For example, a case-controlled study in rural Zimbabwe showed that women with FGS had a three-fold risk of having HIV [17]. A study looking across 43 sub-Saharan countries found that for every S. haematobium infection per 100 individuals, there was a relative increase of $2.9 \%$ in HIV prevalence suggesting an association between infection with S. haematobium and HIV [14]. The local inflammatory response to the parasite eggs includes HIV target cells (CD4 $+\mathrm{T}$ lymphocytes and macrophages) [22] and coupled with the friable epithelium and lesions which can cause bleeding during coitus creates a permissive setting for HIV transmission [23]. Therefore, addressing schistosomiasis can improve women's overall reproductive health and decrease vulnerability to other important reproductive health threats such as HIV. Recently, 
a WHO Technical Working Group on HIV and Schistosomiasis reviewed and summarized the evidence of the association between HIV and schistosomiasis and put forth concrete actions to control the HIV/schistosomiasis syndemic in adolescent girls and young women (AGYW) $[3,23]$. In their systematic review [23] the authors, members of the working group, highlighted the need for training in health care workers as a critical gap to improve the condition of AGYW suffering from both diseases. The work we are presenting through this article, builds upon this evidence, underscoring the need for wider awareness on the disease's characteristics, preventive measures, diagnostic and treatment amongst practitioners that care for the sexual and reproductive health of women and girls.

Many non-specific symptoms such as vaginal discharge and pain that patients present with result in many cases being misdiagnosed as sexuality transmitted infections (STI). The diagnosis of FGS is made clinically through colposcopy or visual inspection identifying lesions on the cervix or vaginal tissue [24]. Lesions are described in the WHO FGS Atlas [25] and include intra-vaginal classic grainy sandy patches, single or clustered grains, homogenous yellow patches, rubbery papules, and abnormal blood vessels as seen in the images in Fig. 2 [25]. In addition, some case reports show hypertrophic or ulcerative lesions on the vagina, vulva, or cervix [26-28]. These lesions have been linked histopathologically, in some cases, to the presence of eggs in the tissue causing inflammatory reactions. Detection of these lesions requires colposcopy, or for large lesions, via visual inspection with a speculum or biopsy. However, colposcopes are not commonly available in most rural endemic settings and therefore most infected individuals are never diagnosed. Even if women are referred to higher levels in the health system, the lesions are often not identified as FGS and again proper treatment is not provided.

When an FGS case is suspected, the appropriate treatment of Schistosoma infection is with $40 \mathrm{mg} / \mathrm{kg}$ of praziquantel as a single dose based weight or according to local guidelines with repeated treatment if risk factors persist. Treatment for school-aged children is donated by Merck kGaA, Darmstadt, Germany, and freely available as a community-based treatment regardless of infection status in a process known as mass drug (or medicine) administration (MDA). As infection in endemic settings is frequently asymptomatic until parasite loads increase and tissue damage has progressed, prevalence at the community level in school-aged children will trigger MDA to reduce morbidity and progression of disease in the population. Individual patient treatment for FGS is also with single dose treatment although clinical trials are ongoing to see if different treatment regimens are more effective. Treatment is most effective when given early; however, the potential for reinfection remains high without improved access to safe water [29]. Lesions found later in life may not resolve with antiparasitic treatments as some eggs remain in tissues despite the death of the adult worms and because of fibrosis and calcification of the lesions. More studies are needed on the treatment of advanced disease.

Recognition and proper treatment of FGS is greatly hampered by the fact that it may not be part of standard medical training. In addition, awareness of the disease is low in both affected communities and health systems of endemic countries leaving women little recourse to address the symptoms and complications associated with FGS [2]. Figure 3 shows the most common cycles of FGS misdiagnosis and treatment. In cycle A, a woman is exposed to contaminated water through activities of daily living and becomes ill. She most commonly seeks care at the local health post where, based on symptoms that likely including vaginal discharge and pain, she is presumptively treated for sexually transmitted infections (STI). The woman would then go to the local pharmacy in the village and get antibiotic treatment for STI. When symptoms do not resolve, treatment may be repeated with non-compliance or re-infection being suspected. Eventual referral to the next level health facility would typically require transport and a longer time away from home and household or work responsibilities. At the next level facility depicted in cycle $\mathrm{C}$, there would likely be a further exam but with a similar outcome, perhaps treating with next-line therapy for STI. The woman would return home and again receive antibiotic treatment and again symptoms would not resolve. This process could be repeated with cultures taken and while awaiting results repeating treatment. Without resolution, the patient would then be potentially referred to the next level facility in cycle D. Upon referral the patient would receive a pelvic exam and cultures and presumptive treatment may commonly be repeated again. If a pelvic exam is done and a lesion visualized, biopsies may be taken which again would result in treatment delays and potentially more aggressive treatment if presumptive diagnosis of cervical cancer is suspected. Every visit, treatment, and referral point in this cycle has financial and opportunity costs for the woman and is a potential loss to follow up. Each heath care visit also represents an opportunity to break this cycle if FGS is suspected, providing the opportunity to go from the pharmacy with the correct treatment and return to an improved state of health. This image also shows the potential role that the pharmacy can play as a common point in the referral cycle. These cycles of misdiagnosis and mistreatment demonstrate the need to increase awareness and knowledge around detection and 


\section{Schistosoma spp.}

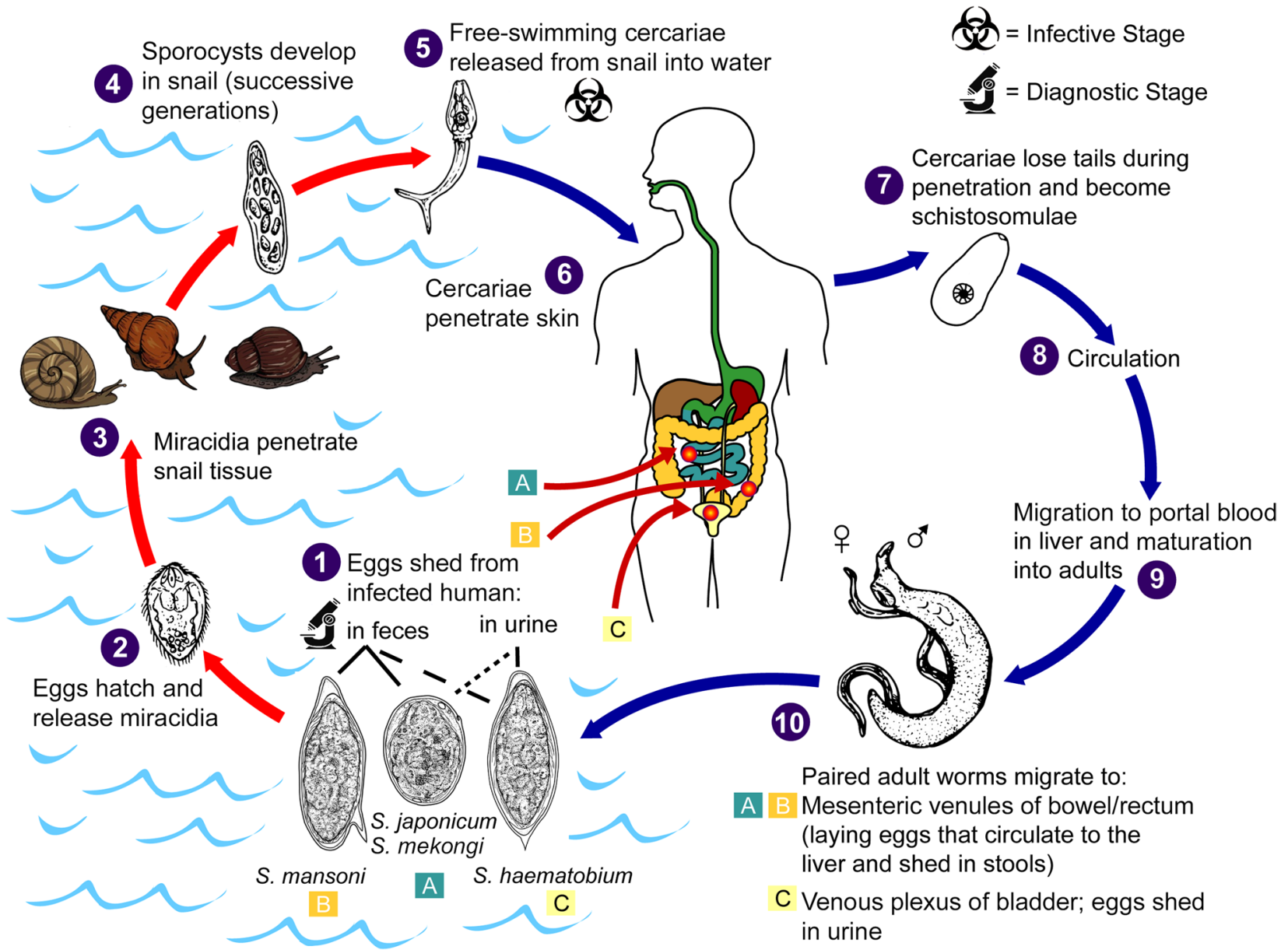

Fig. 1 Transmission cycle of Schistosoma spp. Illustration depicting the life cycle of flatworms of the genus, Schistosoma, the causal agents of the parasitic disease schistosomiasis. A complete description of the Schistosoma haematobium, S. intercalatum, S. japonicum, S. mansoni, S. mekongi life cycle, is [7] available at: https://www.cdc.gov/dpdx/schistosomiasis/index.html. Figure provided by A. J. da Silva and M. Moser for copyright-free dissemination through the Public Health Image Library of the Centers for Disease Control and Prevention

proper treatment of FGS at all levels of the health care system so women and girls no longer have to suffer the consequences of inadvertent misdiagnosis and improper treatment. As a first step, a consistent framework is needed for training health professionals on how to diagnose, treat, and prevent FGS.

As part of the FGS Accelerated Scale Together (FAST) Package project and in collaboration with the WHO

(See figure on next page.)

Fig. 2 Title: Images of confirmed FGS cases. A Quadrants (Q) 3, 7, 9, 11 Homogenous yellow patches with grains interspersed (seen if image is full size. In Q 11 lower right corner abnormal blood vessels can be seen. Abnormal blood vessels can also be seen at the bottom of Q 10. B The classic circular abnormal blood vessels can clearly be seen at the bottom of Q 11 and 12. These circular features can also be seen more subtly in other quadrants. C Grainy sandy patches are seen in Q 2, and also in Q 6-8. Circular abnormal blood vessels are most clearly seen at the top of Q 10 but they are also in Q 6 and 11. D Abnormal blood vessels Quadrants 1-8. The size of the circular abnormal blood vessel is exemplified in Q 9 . Single grains can be seen in Q 2 and 3. E Homogenous yellow sandy patches can be seen in Q 6-7 (and the near in the quadrants around). Circular and uneven-calibered blood vessels are sprawled across this area and there is contact bleeding Q2 and Q7. A Nabothian follicle can be seen in Q 8, here the blood vessels are normal, straighter, evenly branching across the follicle. $\mathbf{F}$ Rubbery papules are seen in Q 5-6 on the anterior surface of the cervix. The anterior fornix is seen at the top of Q 2. G The quadrants. Images were captured by Elisabeth Kleppa and Eyrun Kjetland 


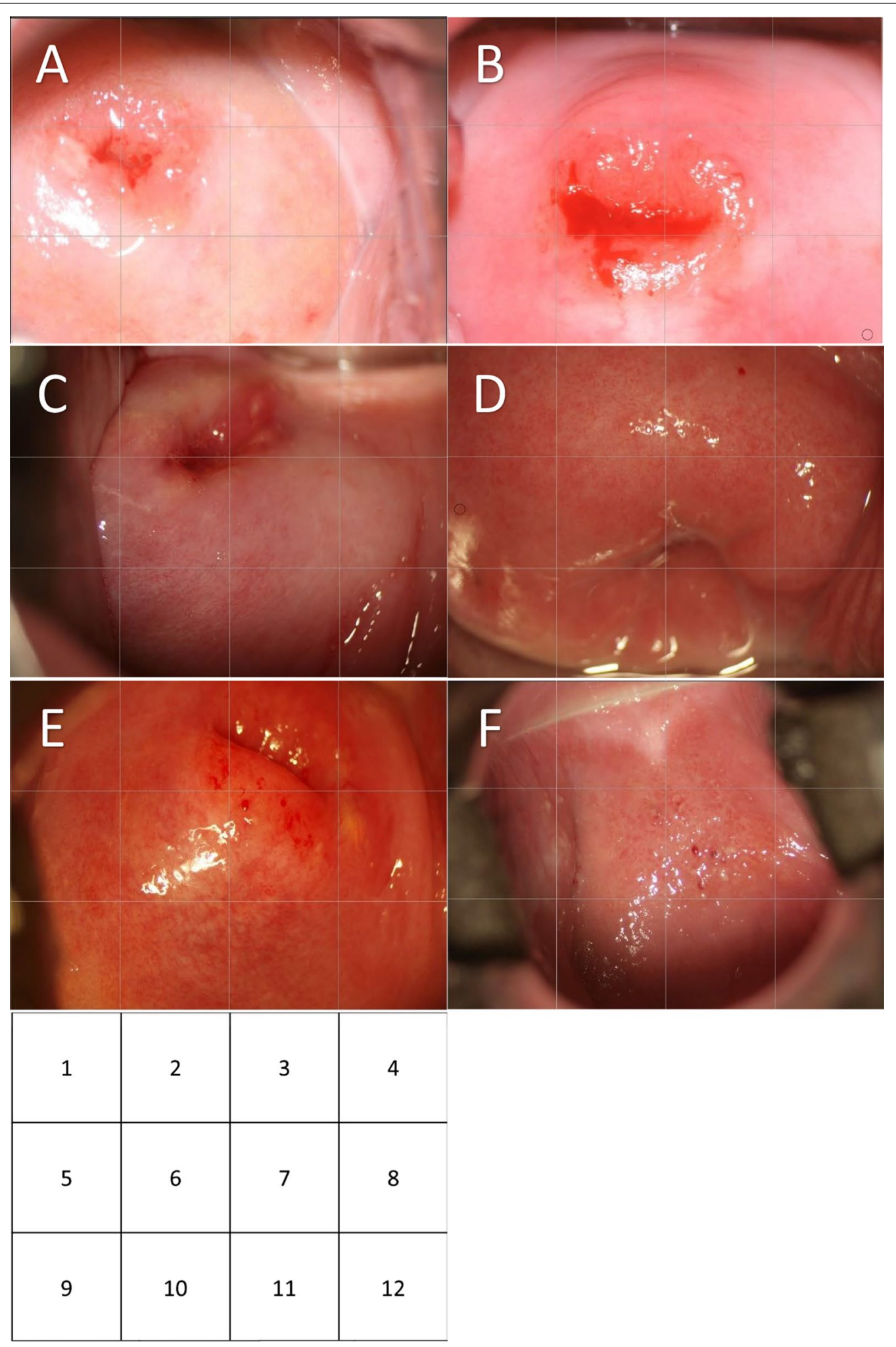

Fig. 2 (See legend on previous page.) 
NTD department, Bridges to Development and the Geneva Learning Foundation conducted a virtual interactive workshop to establish the competencies that are required train health workers in FGS at various levels of the health systems in endemic settings. The objective of this work was to create a durable and openly available resource that any organization, health center, or medical institution can use to facilitate the integration of FGS training into their programs or curricula. We believe that increased awareness of and training for FGS will ultimately help endemic countries address the needs of AGYW at risk of FGS within their health systems.

\section{Methods}

Competencies for FGS are defined as skills, knowledge, and actions required to diagnose, prevent, and treat FGS. The competencies necessary for the management of FGS were developed through a virtual workshop consisting of four sessions taking place over the course of three weeks in July and August 2020. The workshop was hosted by Bridges to Development in collaboration with the WHO and facilitated by the Geneva Learning Foundation (GPLF). The workshop is part of the FAST Package, a project funded by Grand Challenges Canada and the Government of Canada, and was sponsored by the Coalition for Operational Research on Neglected Tropical Diseases (COR-NTD) with funding from the Foreign, Commonwealth, and Development Office (FCDO) of the UK government. The objectives, approach, and proposed outputs of the workshop were developed by a small planning group consisting of members of the WHO NTD Department, select physicians and researchers working in FGS (Table 1). A key goal for the workshop was to engage a diverse group of participants both geographically and professionally to aim for a comprehensive output generalizable to different contexts. The initial list of participants was built upon the networks of the members of the planning group and the WHO team to strategically reach out to appropriate individuals with relevant experience in sexual and reproductive health, health education, parasitic diseases, NTD programs, and public health.

The workshop was divided into four virtual sessions: an introductory session (session 1); two working sessions (sessions $2 \mathrm{a}$ and $2 \mathrm{~b}$ ); and a final review session (session
3). The first, two-hour introductory session included presentations on FGS and the purpose and objectives of the workshop. Also included was an orientation to the highly interactive competency-development and peerreview process to be used in the following working sessions. The second session, which was hosted in both English and French, was divided into two parts to account for the different roles of health professionals and tools available at different levels of the health system. Working session 2a focused on health professionals who work in a clinical setting and who are able to perform pelvic exams either by colposcope or only speculum. Participants in this session included OB/GYNs, physicians, and nurses. Working session $2 \mathrm{~b}$ focused on health professionals who work in a community setting or health clinic who are not able to perform pelvic exams. Participants in this session included community health workers, researchers, parasitologists, pharmacists, and public health practitioners. Lastly, to better focus the workshop, competencies were developed against the five most critical behaviors related to FGS; identify women at risk, prevent, refer, diagnose, and treat. Competencies related to diagnosis of FGS using radiological methods were beyond the scope of this workshop as most surface lesions are too small for radiology [30]. Routine skills in sexual and reproductive health like detection and care for STI, HIV, or cervical cancer, how to take a general history or perform a pelvic exam were beyond the scope of this workshop.

During the two working sessions, participants worked in small groups to develop draft competencies using a template (Table 2) to ensure consistency in structure and elements across each group. Each competency had to answer the following questions: "who, does what, to whom, for what, when, and requiring what background knowledge". Each group's draft competencies were then subject to peer-review. To facilitate the peer-review process, the participants used a collaborative platform called PeerGrade where, using a check list (review rubric), they were prompted to provide concrete, specific, and actionable feedback. At the end of each working session, peerreview feedback was compiled and used to revise the draft competencies.

The final review session allowed participants to review the revised draft competencies and provide final

(See figure on next page.)

Fig. 3 Cycles of FGS Misdiagnosis and Treatment. FGS afflicted woman presents to local health post (A) and leaves to receive treatment at the local pharmacy (B) where she most likely is treated for STI which leaves her with symptoms and this same cycle may be repeated. Without resolution the woman may be referred to the next level health center $(\mathbf{C})$ where again she is most likely treated for STI (B), again without resolution. The woman may be referred to the next level health center (D) where further exam and tests are done however, she again is most likely treated for STI (B) and does not return to her healthy state. With FGS diagnosis at any facility $(\mathbf{A}, \mathbf{C}$, or $\mathbf{D})$ the woman could be treated with praziquantel and returned to a healthy state 


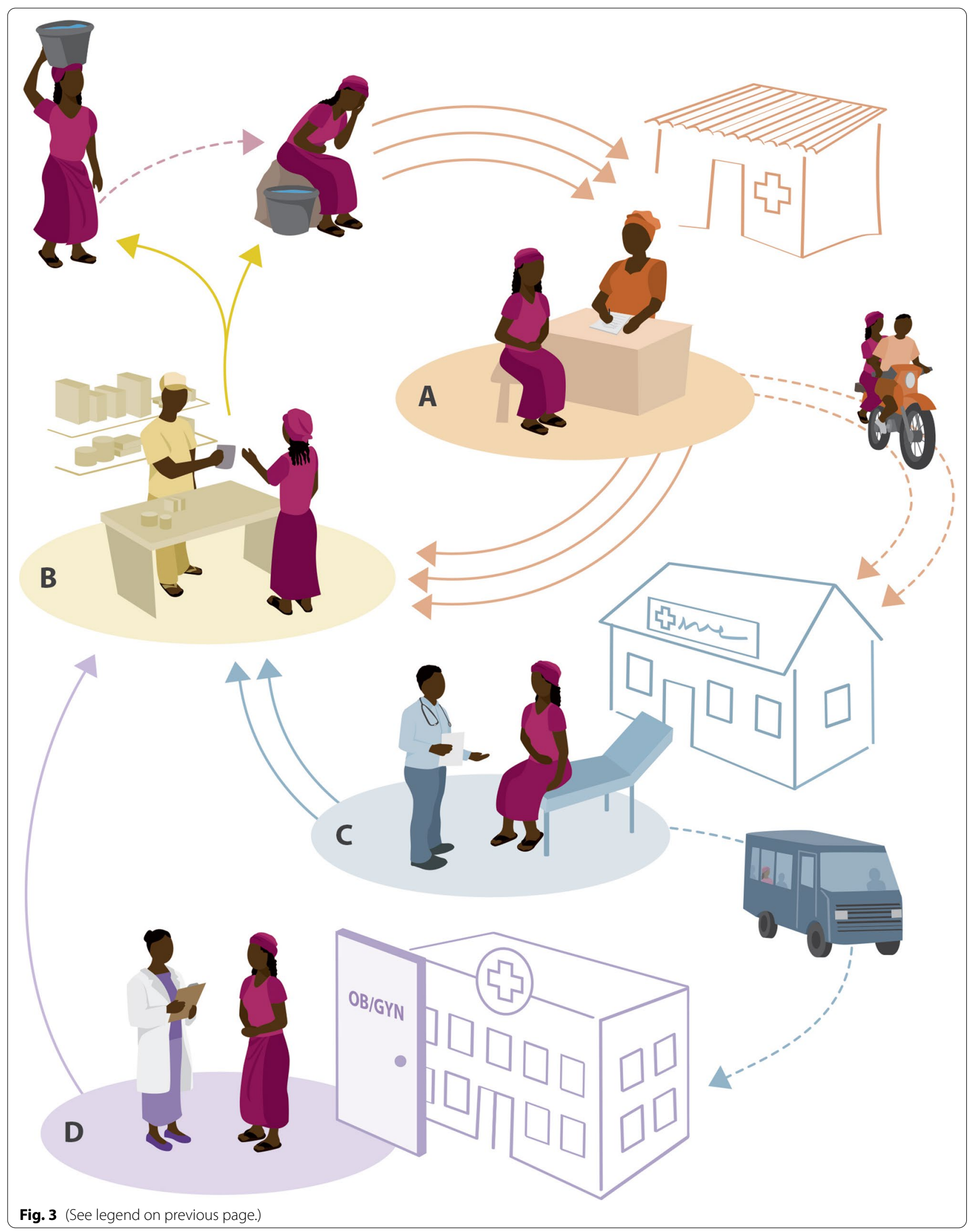


Table 1 Composition of FGS Competencies Workshop Planning Group

\begin{tabular}{|c|c|}
\hline Name & Institution \\
\hline Alain Blaise Tatsinkou & The Geneva Learning Foundation \\
\hline Amadou Garba Djirmay & Word Health Organization \\
\hline Anastasia Pantelias & Bridges to Development \\
\hline Clara Fabienne Rasoamanamihaja & Ministry of Health Madagascar \\
\hline Daniela Fusco & Bernhard Nocht Institute for Tropical Medicine \\
\hline Elisabeth Long & Coalition for Operational Research on NTDs \\
\hline Eyrun Kjetland & $\begin{array}{l}\text { University of KwaZulu-Natal, South Africa/ Oslo University Hospi- } \\
\text { tal, Norway/ BRIGHT Academy, Ugu District, South Africa }\end{array}$ \\
\hline Julie Jacobson & Bridges to Development \\
\hline Kayla Hendrickson & Bridges to Development \\
\hline Kazeem Adebowale Adekunle & University of Sierra Leone teaching hospital complex connaught \\
\hline Mbolatiana Raharinivo & Ministry of Health Madagascar \\
\hline Megan Williamson & Bridges to Development \\
\hline Olabanji Surakat & Osun state University, Nigeria \\
\hline Pamela Sabina Mbabazi & Word Health Organization \\
\hline Reda Sadki & The Geneva Learning Foundation \\
\hline
\end{tabular}

feedback. Again, this work was performed in small groups to benefit from the expertise and experience of all participants. The goal of this work was to ensure that the competencies were clear, relevant and generalizable across participants' countries and contexts. As a final step, the competencies were shared with the WHO NTD program for final review. This step ensured the outputs were aligned with WHO guidelines and the WHO FGS Atlas [25] and that there were no significant gaps. The workshop was evaluated by participants.

\section{Results}

The competencies were developed by 64 participants, consisting of researchers [28], medical doctors [21] and other professions [15] with FGS-related projects, coming from 24 different countries (Fig. 4). Some of the participants had prior experience as nurses or midwives. Most of the "other professions" were pharmacists, parasitologists, or support staff for HIV community programs. The workshop included a high representation of endemic countries with 16 endemic Francophone and Anglophone countries participating (Fig. 5) which helped with

Table 2 Template for drafting FGS competencies

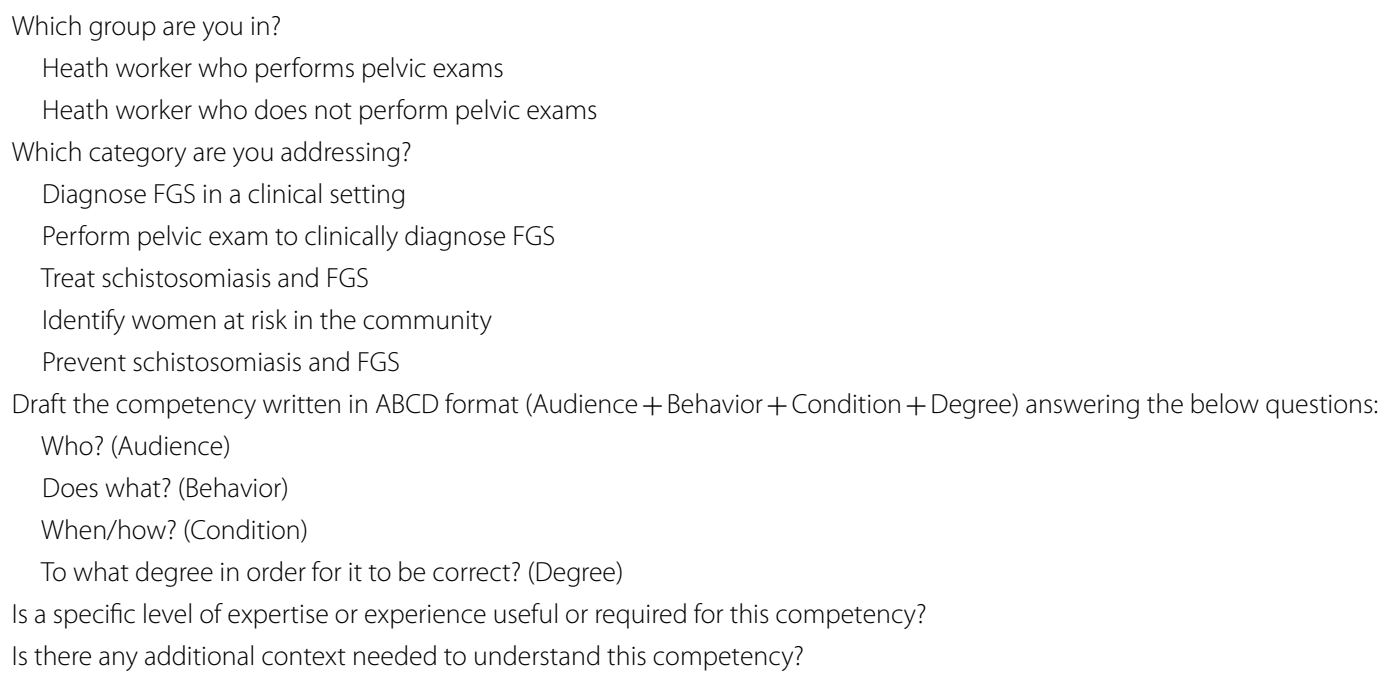


the aim of creating competencies which are as comprehensive and generalizable to endemic areas as possible.

The two interactive workshop sessions ( $2 \mathrm{a}$ and $2 \mathrm{~b}$ ) resulted in approximately 65 draft competencies. After consolidation taking into account the feedback collected on PeerGrade, a set of 31 draft competencies were developed reflecting the input of all participants. Workshop participants discussed and revised this set further prior to submitting to the WHO NTD Program for final comment and approval. As a result of this process, the final output of the workshop included 27 competencies across two categories of health workers: those working in a clinical setting, and those working in a community setting (Fig. 6). The competencies are designed to cover the different steps in caring for an at-risk individual from identifying risk factors, taking of relevant history, counseling on risk for HIV acquisition, and presumptive treatment for FGS. The two-category breakdown reflects the differences in technical resources and knowledge available in these two types of settings. For example, the community competencies are focused on the interactions between a health worker and community members in FGS-endemic areas. Competencies included focus on the ability to ask appropriate questions about symptoms, risk factors, and exposure history to identify those at high risk for FGS. Also included are competencies focused on the ability to deliver information on the disease and how women can access treatment, counsel them on appropriate behaviors to prevent FGS and correctly administer praziquantel to treat women with suspected or confirmed FGS.

The clinical setting competencies address a more purely medical and technical approach in addition to the identification and counseling components described above and focus on the unique attributes of FGS within the context of health seeking for sexual and reproductive health care. For example, the competencies cover behaviors such as diagnosing FGS using a speculum to inspect the women's cervical and all vaginal surfaces for lesions. Included are competencies focused on ordering laboratory tests or performing visual inspection with acetic acid/visual inspection with lugol's iodine (VIA/VILI) to differentiate FGS from STIs or cervical cancer lesions respectfully. Overall, this set of competencies are focused on schistosoma-specific issues and prevention within the context of community contacts for multiple services including sexual and reproductive health needs including HIV and cervical cancer prevention. The detailed description of the final set of 27 competencies can be found in this article's supplementary materials (Additional file 1).

Despite taking place virtually, in a post-workshop survey, $89 \%$ of participants reported learning more about FGS and $100 \%$ reported that the workshop increased their motivation and commitment to the work. Another potential outcome of the workshop is a new FGS Community of Practice as $92 \%$ of participants stated they would like to remain connected moving forward. This increased awareness and motivation around FGS is critical to meaningfully address the burden of this disease. Overall, the results of this work are the first ever comprehensive description of the skills required for health workers, at all levels, to be able to prevent, diagnose, treat, and identify women and girls at risk for FGS. These results can then be used as the basis for training and evaluating health workers on FGS.

\section{Discussion}

To address the burden of FGS across sub-Saharan Africa, it is essential that FGS care and treatment is integrated into routine sexual and reproductive health services where women and girls affected by the parasite will most likely seek care. The workshop identified items that can henceforth be used for training health professionals in

\section{Background}

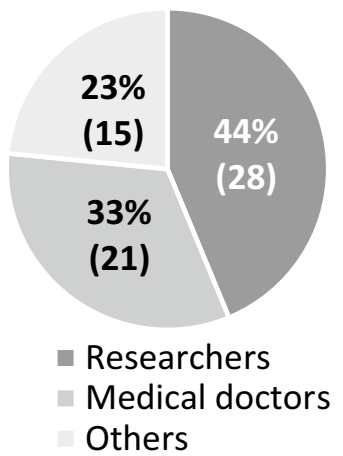

Country of origin

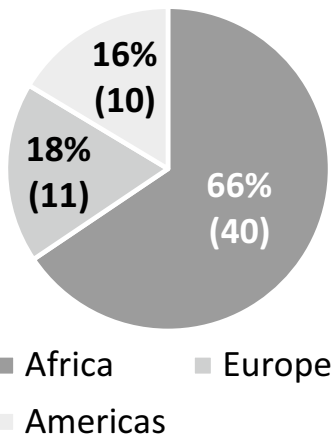

FGS endemic countries

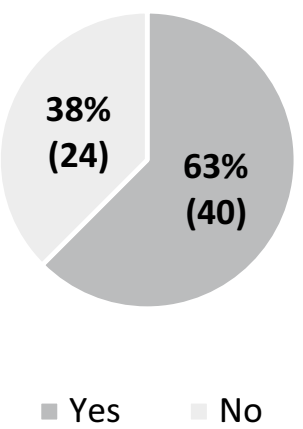

Fig. 4 Breakdown of Workshop participants 


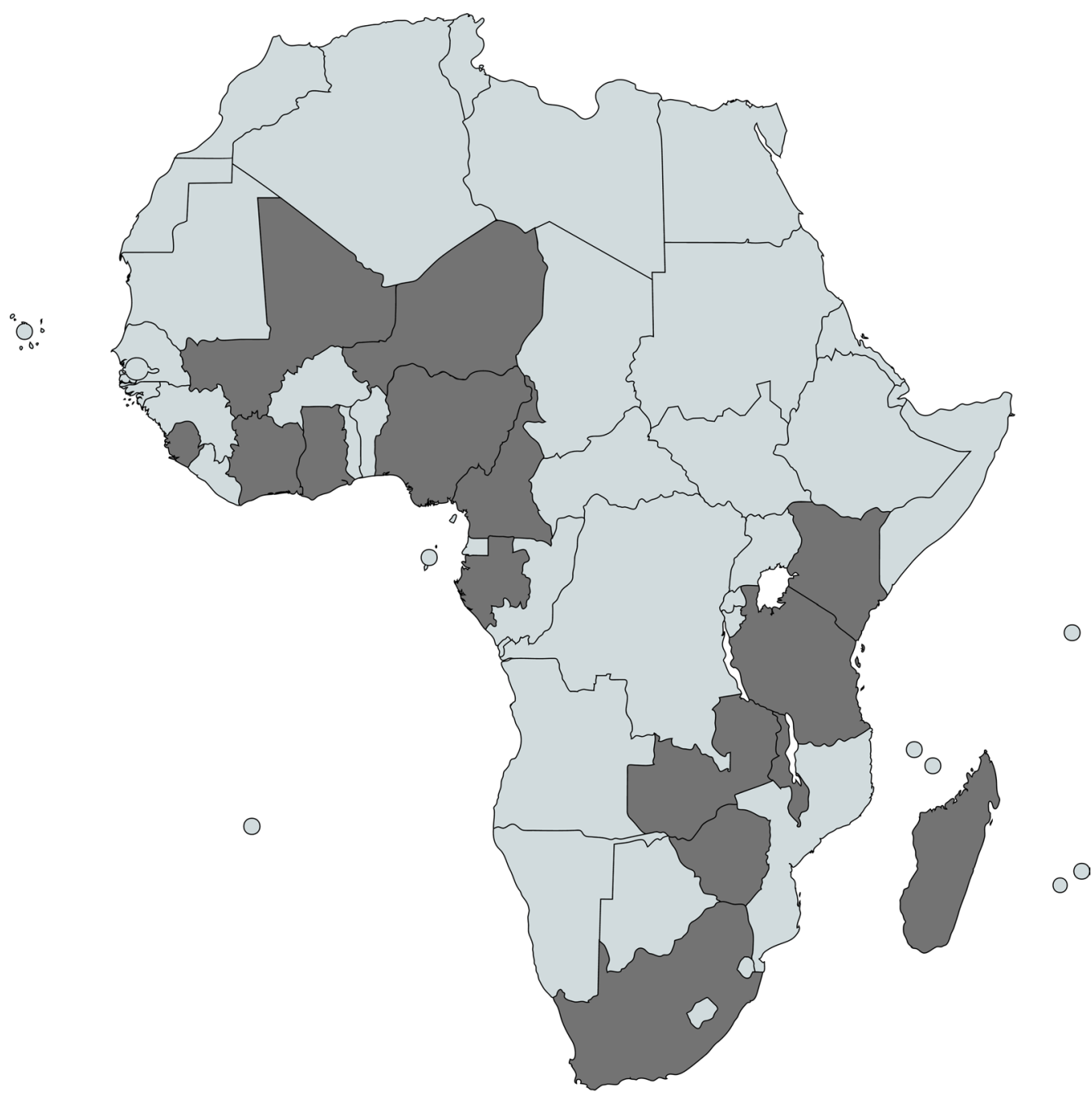

Fig. 5 Map showing countries in which participants reported doing FGS-related work

Created with mapchart net

the management of FGS. Clinicians should be taught how to identify FGS during pelvic exams, what to say to the patient and how to manage the disease. Other health workers should be trained in informing women about FGS and the importance of early preventive chemotherapy.

Due to lack of awareness both in endemic communities and the health care system, FGS remains one of the most important misunderstood areas in women's and girl's health. Lack of knowledge, expertise, and training in health care providers, has resulted in under or misdiagnosis of FGS, limiting access to treatment for women and girls suffering from this preventable and treatable disease. Dr Tedros Adhanom Ghebreyesus, DirectorGeneral, World Health Organization, has stated that
"FGS is a silent and neglected epidemic, affecting the same people who carry a disproportionate global burden of HIV and cervical cancer" [3]. The reproductive health consequences such as infertility, sub-fertility, miscarriage, and ectopic pregnancy are often accompanied by critical social consequences such as discrimination and stigma, particularly when FGS is mistaken for an STI [2, 31]. Therefore, improving health care workers' knowledge by incorporating FGS-related material into medical training curricula can help address this awareness gap and improve women's reproductive health. The first step towards this goal is to clearly define a standardized set of learning outcomes; specifically, the competencies or behaviors required to adequately prevent, diagnose, and manage an FGS case. 


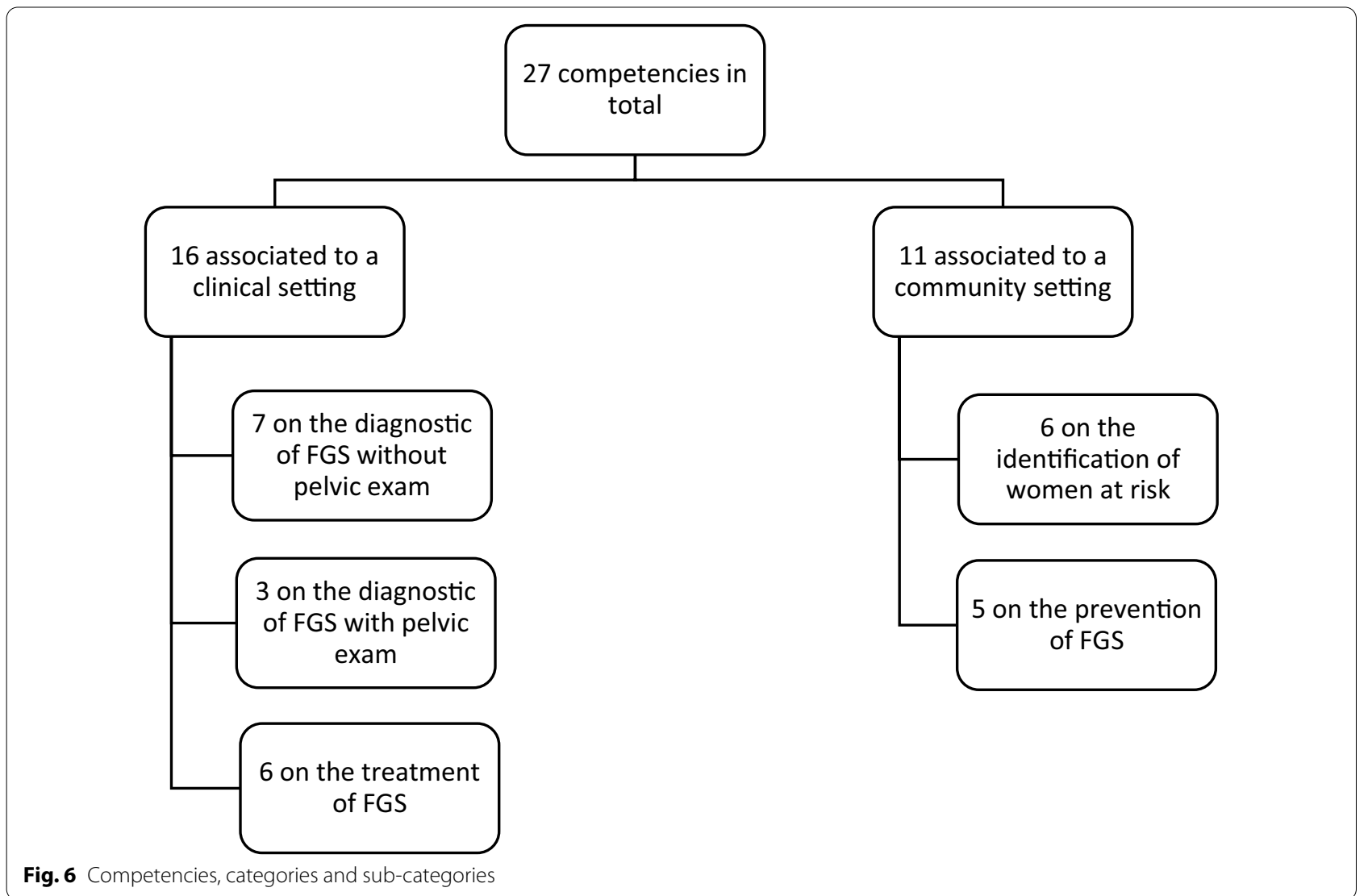

The definition of these competencies is a crucial step towards the appropriate integration of FGS into women's health care. The availability of the FGS competencies can open the door for the development of new, comprehensive training curricula for all health professionals who may contact women and girls at-risk or suffering from FGS. These competencies are a global good, meant to provide the foundation for any program seeking to develop training for FGS.

One of the strengths of the virtual setting for the workshop and the methods used to develop the competencies was the ability to gather input from a highly diverse set of participants and to foster a deeper understanding and awareness of FGS. The diversity of participation was also important for developing competencies which adequately reflect the context in which FGS occurs. For example, as a neglected tropical disease, FGS mainly affects people living in remote areas with limited resources. Health care facilities in endemic areas may not have the tools and interventions needed to diagnose and treat FGS such as colposcopy or praziquantel. Additionally, because FGS is often confused with STIs, affected women and girls often suffer from stigma affecting their ability to access appropriate care [2]. Therefore, particular attention was paid to the different context and environments where FGS cases occur taking into consideration the different health infrastructures, resources and healthcare workers capacities in FGS-endemic countries and communities. This inclusive approach and the diversity of the participants panel resulted in competencies that can likely be adapted and tailored to the environment and settings in which they are being used and the diagnosis of presumed FGS versus clinically confirmed FGS [20].

A limitation of this work is that training of medical professionals alone, while required, is not sufficient to fully address the problem of FGS. Training for FGS needs to be part of a holistic approach to prevention, diagnosis, and treatment which considers the needs at an individual, community, and health-system level. A holistic approach, in addition to training of medical professionals, would include activities such as: (1) building awareness of FGS, associated risk-factors, and reproductive health sequelae in at-risk communities and schools [19]; (2) promoting and ensuring uptake of annual mass drug administration with praziquantel in all schistosomiasis-endemic communities and schools [20, 21]; and (3) integrating diagnosis and treatment of FGS in current algorithms for STIs and cervical cancer and ensuring cases are reported and 
integrated into the routine health management information system [3]. This holistic approach can help decrease the burden of FGS by both preventing new cases and ensuring improved access to appropriate care for women and girls suffering from FGS. This holistic approach will be piloted in Ghana and Madagascar in 2021 under the FAST Package project.

As a next step in this project, new, interactive, digital training modules will be developed against these competencies and piloted with health workers in both Ghana and Madagascar as part of the FAST Package. Further training materials will need to be developed by country programs or their partners and within medical training programs in countries to build on this. To date there are not to our knowledge any standardized training packages available. Several small-scale projects are underway, several being conducted by workshop participants, and these competencies will help, ensure that there is comparability across training outcomes. Continued collaboration across workshop participants and others putting these competencies into curricula will further strengthen programs and allow women and girls to access the services and treatments they need.

\section{Conclusion}

The significant lack of awareness and knowledge from health professionals around FGS has been an obstacle to the improvement of women's reproductive health in many parts of sub-Saharan Africa where schistosomiasis is endemic. The prevalence of the disease in endemic countries can reach very high rates. However, training on FGS remains absent from medical curricula and health worker training materials in most countries. This knowledge gap results in the underdiagnosis, misdiagnosis, and/or lack of or inappropriate treatment for FGS contributing to poor reproductive health outcomes in endemic areas. Incorporating FGS-specific material into the training and education of health professionals can be a highly effective means to improve the prevention, diagnosis and management of FGS cases and consequently improve women's reproductive health and contribute to the advancement of the sexual reproductive health rights agenda for women in Africa. Defining the competencies, to adequately diagnose, treat, and prevent FGS is a necessary first step towards this goal that can be used as a foundation to create new educative tools and materials on FGS for health professionals. By filling this knowledge gap, we hope to see FGS care and prevention integrated seamlessly into sexual and reproductive health services so the needs of this neglected population can be met and the suffering relieved.

\section{Abbreviations}

AGYW: Adolescent girls and young women; COR-NTD: Coalition for Operational Research in Neglected Tropical Diseases; FAST: FGS Accelerated Scale Together; FCDO: Foreign, Commonwealth, and Development Office; FGS: Female genital schistosomiasis; HIV: Human immunodeficiency virus; MDA: Mass drug (or medicines) administration; NTD: Neglected tropical diseases; OR: Odds ratio; VIANILI: Visual inspection with acetic acid/visual inspection with lugol's iodine; WHO: World Health Organization.

\section{Supplementary Information}

The online version contains supplementary material available at https://doi. org/10.1186/s12978-021-01252-2.

Additional file 1. FGS Competencies Table.

\section{Acknowledgements}

The authors would like to acknowledge the contributions of all the members of the FGS Competencies workshop. The following list is not exhaustive and only includes those who responded to a survey requesting their name for acknowledgement in this publication: Alison Krentel, Ashley Preston, Christopher Odianosen Aimakhu, Kristin M Wall, Willis, G.K. Omwoyo, Sammy Olufemi Sam-Wobo, Uwem Ekpo, Ayola Akim Adegnika, Hannah Motshedisi, Sebitloane, Diana Mushiyi, Kazeem Adebowale Adekunle, Alain Blaise Tatsinkou, Obiageli Josephine Nebe, Patricia Doris Ndhlovu, Eyrun F. Kjetland, Amaya L. Bustinduy, Rumbidzai Chabvamuperu, Adekunle Kazeem Adebowale, Florence Wakesho Mwakughu, Bellington Vwalika, Christinet, Victoria A Gamba, Mbolatiana Michèle Raharinivo, Nassar Sulaiman Adebayo, Verner N. Orish, Emmanuel S. K. Morhe, W. Evan Secor, Monsuru Adeleke, Adeleye Abiodun Adeomi, Fiona Fleming, Marrium Habib, Felicia Wong, Olabanji Surakat, Marc Steben, Winnie Chepng'eno

\section{Authors' contributions}

JJ, AP, MW developed and facilitated the competencies workshop, prepared the outputs, managed reviews, and wrote the manuscript. EFK contributed the FGS images and captions and reviewed the article. AK \& MG contributed to the planning of the workshop, reviewed and provided content for the article. AGD \& PSM provided final review and edits for the competencies and reviewed and provided content for the article. All authors have read and approved the manuscript.

\section{Funding}

The workshop was supported by the Coalition for Operational Research on Neglected Tropical Diseases (COR-NTD), which is funded at The Task Force for Global Health primarily by the Bill \& Melinda Gates Foundation, by the UK aid from the British government, and by the United States Agency for International Development through its Neglected Tropical Diseases Program. The FAST Package project is supported by funding from Grand Challenges Canada and the Government of Canada with match funding provided by the NTD Support Center, Merck Global Health Institute, the SCI Foundation and WHO ESPEN. Publication costs were supported by Merck Global Health Institute.

Availability of data and materials

Data and materials are available on request.

\section{Declarations}

Ethics approval and consent to participate

Not applicable.

Consent for publication

Not applicable.

Competing interests

The authors declare that they have no competing interests. 


\begin{abstract}
Author details
'Bridges to Development, Washington, USA. ${ }^{2}$ University of Geneva, Geneva, Switzerland. ${ }^{3}$ Discipline of Public Health Medicine, Nelson R Mandela School of Medicine, College of Health Sciences, University of KwaZulu-Natal, Durban 4041, South Africa. ${ }^{4}$ School of Epidemiology and Public Health, Faculty of Medicine, University of Ottawa and Bruyère Research Institute, Ottawa, Canada. ${ }^{5}$ Institute of Health Research, University of Health and Allied Sciences, Ho, Ghana. ${ }^{6}$ Department of Control of Neglected Tropical Diseases, World Health Organization, Geneva, Switzerland. ${ }^{7}$ Norwegian Centre for Imported and Tropical Diseases, Department of Infectious Diseases Ullevaal, Oslo University Hospital, 0450 Oslo, Norway.
\end{abstract}

Received: 24 March 2021 Accepted: 27 September 2021

Published online: 24 January 2022

\section{References}

1. Swai B, Poggensee G, Mtweve S, Krantz I. Female genital schistosomiasis as an evidence of a neglected cause for reproductive ill-health: a retrospective histopathological study from Tanzania. BMC Infect Dis. 2006;6(1):134.

2. Kukula VA, MacPherson EE, Tsey IH, Stothard JR, Theobald S, Gyapong M. A major hurdle in the elimination of urogenital schistosomiasis revealed: Identifying key gaps in knowledge and understanding of female genital schistosomiasis within communities and local health workers. PLoS Negl Trop Dis. 2019;13(3):e0007207

3. Joint United Nations Programme on HIV/AIDS (UNAIDS). No more neglect-Female genital schistosomiasis and HIV [Internet]. 2019 [cited 2021 Feb 2]. Report No.: UNAIDS/JC2979. https://www.unaids.org/sites/ default/files/media_asset/female_genital_schistosomiasis_and_hiv_en. pdf.

4. WHO. WHO Fact sheet Schistosomiasis [Internet]. 2020 [cited 2020 Sep 22]. https://www.who.int/news-room/fact-sheets/detail/schistosomiasis.

5. O'Brien DP, Ford N, Djirmay AG, Calmy A, Vitoria M, Jensen TO, et al. Female genital schistosomiasis and HIV: research urgently needed to improve understanding of the health impacts of this important coinfection. JAIDS J Acquir Immune Defic Syndr. 2019;80(5):489-93.

6. Yirenya-Tawiah DR, Ackumey MM, Bosompem KM. Knowledge and awareness of genital involvement and reproductive health consequences of urogenital schistosomiasis in endemic communities in Ghana: a crosssectional study. Reprod Health. 2016;13(1):117.

7. Da Silva A, Moser M. Illustration of the life cycle of the parasitic agents responsible for causing schistosomiasis [Internet]. Public Health Image Library, Centers for Disease Control and Prevention; 2002. http://phil.cdc. gov/phil/details.asp?pid=3417.

8. World Health Organization. Women and Health: Today's Evidence Tomorrow's Agenda (Nonserial Publications) [Internet]. 1st ed. World Health Organization; 2010 [cited 2021 Feb 2]. https://apps.who.int/iris/bitstream/ handle/10665/44168/9789241563857_eng.pdf;jsessionid=11F0C38D1C E0CF58EA0FA9D8B38DD42F? sequence $=1$

9. Ekpo UF, Odeyemi OM, Sam-Wobo SO, Onunkwor OB, Mogaji HO, Oluwole AS, et al. Female genital schistosomiasis (FGS) in Ogun State, Nigeria: a pilot survey on genital symptoms and clinical findings. Parasitol Open [Internet]. 2017 ed [cited 2020 Nov 19];3. https://www.cambridge. org/core/journals/parasitology-open/article/female-genital-schistosom iasis-fgs-in-ogun-state-nigeria-a-pilot-survey-on-genital-symptoms-andclinical-findings/FAA1999928C361F63B5A93FEFE176739.

10. Yirenya-Tawiah D, Amoah C, Apea-Kubi KA, Dade M, Ackumey M, Annang T, et al. A survey of female genital schistosomiasis of the lower reproductive tract in the Volta basin of Ghana. Ghana Med J. 2011;45(1):16-21.

11. Engels D, Hotez PJ, Ducker C, Gyapong M, Bustinduy AL, Secor WE, et al. Integration of prevention and control measures for female genital schistosomiasis, HIV and cervical cancer. Bull World Health Organ. 2020;98(9):615-24.

12. Woodall PA, Kramer MR. Schistosomiasis and Infertility in East Africa. Am J Trop Med Hyg. 2018;98(4):1137-44.

13. Friedman JF, Mital P, Kanzaria HK, Olds GR, Kurtis JD. Schistosomiasis and pregnancy. Trends Parasitol. 2007;23(4):159-64.
14. Mbah MLN, Poolman EM, Drain PK, Coffee MP, van der Werf MJ, Galvani AP. HIV and Schistosoma haematobium prevalences correlate in subSaharan Africa. Trop Med Int Health. 2013;18(10):1174-9.

15. Brodish $\mathrm{PH}$, Singh K. Association between Schistosoma haematobium exposure and human immunodeficiency virus infection among females in Mozambique. Am J Trop Med Hyg. 2016;94(5):1040-4.

16. Downs JA, Dupnik KM, van Dam GJ, Urassa M, Lutonja P, Kornelis D, et al. Effects of schistosomiasis on susceptibility to HIV-1 infection and HIV-1 viral load at HIV-1 seroconversion: a nested case-control study. PLoS Negl Trop Dis. 2017;11(9):e0005968.

17. Kjetland EF, Ndhlovu PD, Gomo E, Mduluza T, Midzi N, Gwanzura L, et al. Association between genital schistosomiasis and HIV in rural Zimbabwean women. AIDS. 2006;20(4):593-600.

18. Petry KU, Scholz U, Hollwitz B, Wasielewski RV, Meijer CJLM. Human papillomavirus, coinfection with Schistosoma hematobium, and cervical neoplasia in rural Tanzania. Int J Gynecol Cancer [Internet]. 2003;13(4). https://ijgc.bmj.com/content/13/4/505.

19. Kjetland EF, Ndhlovu PD, Mduluza T, Deschoolmeester $V$. The effects of genital Schistosoma haematobium on human papillomavirus and the development of cervical neoplasia after five years in a Zimbabwean population-The impact of Schistosoma haematobium on persistent HPV in rural Zimbabwean women at high-risk was investigated. Eur J Gynaecol Oncol. 2010;31(2):169.

20. Sturt AS, Webb EL, Francis SC, Hayes RJ, Bustinduy AL. Beyond the barrier: female Genital Schistosomiasis as a potential risk factor for HIV-1 acquisition. Acta Trop. 2020;209:105524.

21. Leutscher PDC, Ramarokoto C-E, Hoffmann S, Jensen JS, Ramaniraka V, Randrianasolo B, et al. Coexistence of urogenital schistosomiasis and sexually transmitted infection in women and men living in an area where Schistosoma haematobium is endemic. Clin Infect Dis. 2008;47(6):775-82.

22. Jourdan PM, Holmen SD, Gundersen SG, Roald B, Kjetland EF. HIV target cells in Schistosoma haematobium-infected female genital mucosa. Am J Trop Med Hyg. 2011;85(6):1060-4.

23. Patel P, Rose CE, Kjetland EF, Downs JA, Mbabazi PS, Sabin K, et al. Association of schistosomiasis and HIV infections: a systematic review and metaanalysis. Int J Infect Dis IJID Off Publ Int Soc Infect Dis. 2020.

24. Helling-Giese G, Sjaastad A, Poggensee G, Kjetland EF, Richter J, Chitsulo L, et al. Female genital schistosomiasis (FGS): relationship between gynecological and histopathological findings. Acta Trop. 1996;62(4):257-67.

25. WHO D of control of neglected tropical diseases. Female genital schistosomiasis: A pocket atlas for clinical health-care professionals [Internet]. Dr Garba Djirmay A, Dr Mbabazi P, editors. WHO reference number: WHO/ HTM/NTD/2015.4; 2015. https://apps.who.int/iris/bitstream/handle/ 10665/180863/9789241509299_eng.pdf?sequence $=1$.

26. Madden F. The incidence of Bilharziosis in Egypt and its clinical manifestations. Br Med J. 1910;965-9.

27. Leutscher P, Ravaoalimalala VE, Raharisolo C, Ramarokoto CE, Rasendramino M, Raobelison A, et al. Clinical findings in female genital schistosomiasis in Madagascar. Trop Med Int Health TM IH. 1998;3(4):327-32.

28. Leutscher P, Raharisolo C, Pecarrere JL, Ravaoalimalala VE, Serieye J, Rasendramino M, et al. Schistosoma haematobium induced lesions in the female genital tract in a village in Madagascar. Acta Trop. 1997;66(1):27-33

29. Kjetland EF, Ndhlovu PD, Kurewa EN, Midzi N, Gomo E, Mduluza T, et al. Prevention of gynecologic contact bleeding and genital sandy patches by childhood anti-schistosomal treatment. Am J Trop Med Hyg. 2008;79(1):79-83.

30. Norseth HM, Ndhlovu PD, Kleppa E, Randrianasolo BS, Jourdan PM, Roald $B$, et al. The colposcopic atlas of schistosomiasis in the lower female genital tract based on studies in Malawi, Zimbabwe, Madagascar and South Africa. PLoS Negl Trop Dis. 2014;8(11):e3229.

31. Hotez PJ, Harrison W, Fenwick A, Bustinduy AL, Ducker C, Mbabazi PS, et al. Female genital schistosomiasis and HIV/AIDS: reversing the neglect of girls and women. PLoS Negl Trop Dis. 2019;13(4):e0007025.

\section{Publisher's Note}

Springer Nature remains neutral with regard to jurisdictional claims in published maps and institutional affiliations. 